\title{
ALLITERATION IN THE KALEVALA AND IN THE TRANSLATION OF THE EPIC INTO KOMI BY ADOLF TURKIN
}

\author{
Nikolay Rakin \\ University of Tartu
}

\begin{abstract}
Alliteration is one of the leading stylistic features characteristic of the Kalevala. This analysis of the translation of the Kalevala into Komi by Adolf Turkin shows that alliteration is fairly frequent in the target text. Examples of alliteration and data on the occurrences of alliteration in the translation allow the suggestion that the translator may have attempted to make use of consonant words. However, alliteration observed in the translation cannot be regarded as a characteristic phonetic factor that participates in the organisation of the text. It proves to be accidental, not structural (as it is in the original text of the Kalevala). In the translation, which has 5132 lines, alliteration is observed in 1539 lines, or nearly in one-third of the translation. In the major part of the examples weak alliteration occurs; strong alliteration is fairly rare. In the text of translation, alliteration is expressed by different word-initial sounds, the overall number of which is 28 ( 21 consonants and 7 vowels). It is frequent in words that begin with the consonants $[\mathrm{k}],[\mathrm{v}],[\mathrm{p}],[\mathrm{m}]$ and $[\mathrm{s}]$. Among the occurrences of strong alliteration there are cases in which a syllable or the root of the word is repeated ( $25 \%$ in each case). The fact that the structural features of the Komi language differ from those of the Finnish literary language (and of the language of the Kalevala) explains the limitations in the translation of such a device as alliteration. From the point of view of the differences in the phonetic features it can be noted that Komi has, for example, 33 phonemes ( 7 vowels and 26 consonants) while in Finnish the phonemes are less numerous: 21 (8 vowels and 13 consonants). Hence, words with the same initial consonants are fewer in Komi. As far as lexis is concerned, consonant-initial words that would make pairs of synonyms (both in the literary language and dialects) are fairly rare.
\end{abstract}

Keywords: the Kalevala, alliteration, Komi language, translation

DOI: http://dx.doi.org/10.12697/jeful.2015.6.1.08

\section{Introduction}

The term alliteration is considered to have been first used in Italy (Leino 1970: 11, Semenova 2001: 113). The definition of this term by different 
authors across cultures and languages has varied over time. Alliteration has been defined as the repetition of sounds in the word-initial, or in the stressed, syllable; the repetition of any consonants, or of combinations of consonants; and as the repetition of word-initial vowels. In Germany, for example, no differentiation has been made concerning the vowel and consonant sounds involved in alliteration. In the UK, an analogous attitude has been observed; although alliteration has also been viewed as a phenomenon that involves only the consonant sounds (word-initial as well as those that occur in any other position). Alliteration in Russia has been regarded to be consonance in which only similar consonants occur. Estonian researchers distinguish between consonance, which is synonymous to alliteration, and assonance, which is the repetition of vowels. Taken together, these kinds of repetition constitute the notion of initial rhyme (algriim) (Leino 1970: 11-12, Laugaste 1962: 531, Semenova 2001: 113).

In the works of Finnish authors, alliteration has been regarded as the consonance of the consonant and vowel sounds that occur at the beginning of the word; distinction has been made between strong and weak alliteration (vahva/heikko alkusointu). In the case of strong alliteration similar word-initial consonants followed by similar vowels, as well as similar word-initial vowels, occur in several words of a line. Weak alliteration is the repetition of similar consonants followed by different vowels, it may also be expressed by word-initial vowels that are not similar (Leino 1970: 11).

Examples of alliteration from the Kalevala: a) strong alliteration, b) weak alliteration

a)

Pane paita palttinainen,

liitä liinan-aivinainen... (4: 171-172)

$\underline{\boldsymbol{O}}$ tti $\underline{\text { olkisen }} \underline{\boldsymbol{o}}$ rihin,

hernevartisen hevosen... (6: 5-6)

b)

Viikon $\underline{\text { vu} o t t i ~ V a ̈ ̈ i n a ̈ m o ̈ i s t a ̈, ~}$ viikkon $\underline{\boldsymbol{u}}$ otti, ei $\underline{\boldsymbol{v}}$ äsynyt... (6: 65-66)

É $i$ ollut iässä pilvi... (6: 87)
Put on a shirt of unbleached linen, Upon it add a linen one...

Took a stallion of the colour of straw, A pea-green horse...

For long awaited Väinämöinen, Awaited long, was not tired...

There was no cloud in the east... 
Alliteration is one of the leading stylistic features characteristic of Kalevala verse, which is based on eight-syllable trochaic lines. Alliteration is usually freely located within the line. Despite the fact that it belongs to one of the characteristic features of Kalevala verse, it is by no means obligatory: almost $20 \%$ of the Kalevala lines lack alliteration. Kalevala verse supposedly dates back to the Proto-Finnic period as it is known to exist in the poetry of the majority of the Finnic peoples. As to alliteration (and parallelism), it is older than the eight-syllable Kalevala line. Alliteration started developing when folk poetry was brought into being; it was a device used in the creation of the Kalevala poetic form (Leino 1970: 12).

\section{Development and use of alliteration}

According to Eduard Laugaste (1962: 531), alliteration started developing as word repetition. Later, the words were changed (or substituted) in order to achieve variation: the first syllable or sound remained unchanged, the subsequent sound was substituted, and the consonant or the vowel of the stressed syllable was changed.

Mentioning the opinion of other authors, Pentti Leino (1970: 18) thus describes the possible way of the development of alliteration (as well as of the rhyme and of the sound repetition in a line). Within a group of phrases, some of the sounds happened to be accidentally repeated. Both the speaker and the listener instinctively noticed that the phrases, in which repetition occurred, produced a special effect. Such phrases were memorised and later, when it was appropriate, they were used in order to emphasise an utterance. Analogous phrases were produced either involuntarily or deliberately - thus the use of alliteration (and of rhyme) was made more extensive.

The use of alliteration in the Finnic languages and, first of all, in the runes of Kalevala verse has been ascribed to the influence of Germanic languages. However, alliteration in the verses of Germanic and Finnic peoples might have had different roots and have developed apart. In the verses of other Finno-Ugric peoples, alliteration is known to be used in the Mordvin and Mari languages. It also occurs in Hungarian, Khanty, and Mansi verses (Leino 1970: 13, Laugaste 1968: 1881).

According to Pentti Leino (1970: 19), alliteration is in a natural way associated with the resources of a given language, its uses and development largely depend on the structure of the language. Laugaste (1962: 
532) notes that alliteration is most of all characteristic of the folklore of those peoples whose languages have word-initial stress.

Alliteration is considered to be one of the building blocks of verse and it also serves for mnemonic and aesthetic purposes. As a building block in a structure, alliteration requires that a word is followed on a line by another word of a definite type. Being tightly connected these words have, from the point of view of the content of the phrase, more significance than the other words, they cannot easily be changed or substituted. The meaning of the phrase is emphasised through alliteration, which is based on the related words. Thus, alliteration influences the choice of words. With time, a great number of word combinations, stereotype expressions, and lines based on alliteration have been produced. Through the use of idiom-like and idiomatic word combinations, doublets and paired words in the language, alliteration has gradually grown into a system (Laugaste 1962: 531, Laugaste 1968: 1874).

Alliteration, which offers a reduced choice of words, eases the process of memorising lines. This mnemonic function of alliteration is of great importance for the performers, or the transmitters, of oral poetry. It is realised in singing, as well as in minor forms, through the medium of stereotype expressions and certain combinations of words. The idioms that occur in many songs do not carry information about where they were first used.

Folklore is transmitted through singing and speech, this is why alliteration as a medium that transmits sounds also produces a certain aesthetic effect. The three functions of alliteration are manifested simultaneously (Laugaste 1968: 1874-1875, Leino 1970: 21).

Alliteration and parallelism are, according to researchers, interrelated. Both phenomena are particular types of repetition, which is a broad notion. Different kinds of repeated sound, words, lines, episodes, and ideas, including alliteration and parallelism, constitute one of the inherent components of runic verses. Within a parallel group, synonymy relations are observed between separate parts, due to this relationship, interdependence between the words that occur in the lines is established in the same way as in alliteration. Parallelism participates in the creation of images while alliteration has a role to play in the development of the images. The performer uses alliteration as an effective means that helps to develop the creation of an image (Laugaste 1968: 1880, Leino 1970: 18).

Eduard Laugaste (1968: 1879-1880) in his analysis of Estonian folk verse has established that among the categories of words most frequently used in alliteration are adjectives, numerals, nouns, and verbs. It is 
our belief that a similar observation can be also made concerning the Kalevala runes. In fact, attributes, including numerals, are often used with the words they define to produce alliteration. Proper names and place names also occur as consonant words. Adverbs, pronouns, and conjunctions prove to be less liable to alliteration. The independent parts of phrases occur in alliteration twice as rarely as the parts that are dependent (or connected with another part of a phrase). The predicate and the object are the sentence members that are most frequently used for alliteration.

As a rule, alliteration is observed within one line. However, it may be extended to further lines - over one, two, three, and sometimes even four lines, thus, it forms a chain. This happens rarely and has no special significance, however, such alliteration causes strong dependence between the lines (Laugaste 1968: 1880, Laugaste 1962: 537).

\section{Example:}

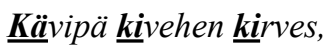

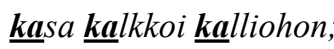

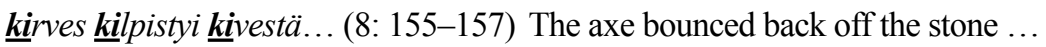

An axe hit the stone,
The tip of the blade - the rock;

With respect to the location of consonant words or pairs of words in a line, several types of alliteration can be identified, as shown below.

Alliteration, or the consonance, of

- the first and the second word (1+2: $\underline{\text { Su}}$ ihki sukkula piossa (8: 11) 'hummed the shuttle in the palm');

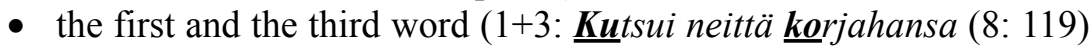
' $[\mathrm{He}]$ called the maiden into [his] sledge');

- the second and the third word (2+3: peitti maassa marjan varret (8: 189) 'in the soil flooded [blood] the stems of the berries');

- two pairs of words: the first and the second word with the third and

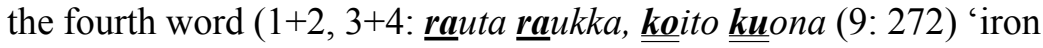
poor, miserable slag'); the first and the third word with the second and the third word (1+3, 2+4: $\underline{\text { En }} \underline{\underline{\text { liik }}}$ u $\underline{\text { omin }} \underline{\underline{\text { lihhoini }}}$ (9: 507) 'I don't move by my body').

The consonance of two different pairs is only possible in lines that contain four or more words. Alliteration, which occurs in pairs of words, varies in its intensity - one pair usually has stronger consonance than the other pair or pairs (Semenova 2001: 115-116). 
Alliteration occurs not only in the Kalevala runes and in the Kalevala folklore verse. It can be found in proverbs, sayings, riddles, tongue twisters, counting rhymes, laments, as well as in the genres of prose. Alliteration plays a significant role in phraseology and it is used in contemporary poetry, in the language of advertisements, posters, and the titles of books and films. For this reason, alliteration is used neither as a criterion for drawing the borderline between new and old folklore, nor between ethnic and contemporary professional poetry (Leino 1970: 12-13, Laugaste 1962: 531, 537).

Pentti Leino (1970: 22) distinguishes between structural (compulsory and facultative, or optional) alliteration and occasional (or accidental) alliteration. The latter produces sound effects and is frequently found in lyric poems. The major criterion that he uses to differentiate between these two types is the occurrences of sound repetitions. Structural alliteration occurs more frequently than accidental alliteration. It remains active throughout the whole process of text creation, while occasional alliteration is activated only in separate points of the process. In the case of structural alliteration, the phonetic factor influences the choice of words more than, for example, rhyme and assonance do.

\section{Kalevala and the Komi translation}

Alliteration that occurs in the Kalevala is of the structural type. Accidental alliteration is observed, for example, in Russian (Karhu 1978: 124).

Examples of sound repetition in the Komi translation of the Kalevala by Adolf Turkin (runes 1-10, 34, 40, 41, 44: Turkin 1980, 1984, 1985a, 1985b, 1985c, 1985d, 1987, 1991, 1996, 1999, 2000a, 2000b, $2000 \mathrm{c}, 2000 \mathrm{~d}, 2000 \mathrm{e}$ ) can be considered accidental alliteration. According to the author, it is not possible to convey the stylistic device of alliteration used in the epic by means of the Komi language (Turkin 1985e: 9). However, the analysis of the translation shows that alliteration (as defined in the aforementioned Finnish tradition) appears fairly frequently in the Komi text.

In the translation, which has 5132 lines, alliteration is observed in words that appear in 1539 lines. This means that alliteration occurs nearly in each third line of the translation.

Alliteration is the most numerous in the lines of rune 9 (211 lines). It appears fairly frequently in the lines of the following runes: 4 (165 
lines), 3 (149 lines), 10 (120 lines), 44 (119 lines), 40 (111 lines), 7 (108 lines), 2 (106 lines), 1 (97 lines), 41 (77 lines), 8 and 34 (73 lines in each), 6 (66 lines) and 5 (64 lines). The occurrence of alliteration is the highest as a percentage in runes 9 and $44(36 \%$ of the lines in each rune) and fairly high in runes 40 (33\%), 4 (32\%), 41 (31\%), 1 and 34 (30\% in each rune). In the other runes alliteration is less frequent (in $26-29 \%$ of the lines).

In the majority of cases weak alliteration is observed (1235 lines, or $80 \%$ of the overall number of cases). Strong alliteration is fairly rare (249 lines, or 17\%). In the remaining cases ( 55 lines, or 3\%) alliteration of a mixed type, i.e. the consonance of two different pairs of words, occurs.

Alliteration that occurs in the translation is expressed by different word-initial sounds, the overall number of which is 28 (21 consonants and 7 vowels). The most frequent is the use of words that begin with the consonant $\kappa(34 \%$, or one third of all the cases of consonance); less frequent are words with the consonant 8 at the beginning $(23 \%$ of all consonance). The occurrence of words with other initial letters are comparatively few: $n(11 \%), \mu(10 \%)$, and $c(5 \%)$; in $15 \%$ of the cases of consonance, the sounds $m, \sigma, c b, \pi, 4, \partial, 2, \mu b, \breve{u}, u, H, з, \varkappa, \partial 3, p, л b$ occur. Words with initial vowels $(o, y, \ni, a, u, \ddot{o}, b l)$ constitute $2 \%$ of all cases of alliteration. No alliteration is observed in words that begin with the sounds $\partial b, \partial \mathcal{H}, 3 b, m u, m b$.

Strong alliteration, which occurs when there is a complete consonance of the first syllable of the words involved, is observed in words with such combinations of sounds as $к о, к \ddot{о}, в о, в \ddot{о}, л y, м е, м y, n \ddot{o}, \kappa b l$, $c u, u y, \partial o, n o, \breve{u} o(=\ddot{e}), в e, c b b l, m y, u o$ (the combinations of sounds are presented according to the descending frequency of occurrence). There are 64 variants of syllables that occur as strong alliteration. In $25 \%$ of the cases of strong alliteration, repetition of the same syllable occurs, the root of the word is also repeated in $25 \%$ of the cases.

Several types of alliteration are identified with respect to the number of words involved in consonance:

$$
\begin{aligned}
& a-a, \\
& a-a-a, \\
& a-a-a-a, \\
& a-a+b-b, \\
& a-a+b-b-b .
\end{aligned}
$$


Either strong or weak alliteration is present in the first type. In the other types strong, weak, as well as mixed alliteration occurs. This means that one group of components creates strong alliteration and the other group creates weak alliteration.

\section{a-a}

This type of alliteration was found to be the most frequent in the translation - it occurs in 1365 lines ( $88 \%$ of the overall number of lines). In the majority of them (1138, or $83 \%)$, weak alliteration is observed. In the remainder of these lines (277, or 17\%), strong alliteration occurs. As each line of the translation contains 5-7 words, the location of the consonant words in a line allowed the identification of 15 variations (out of 20 possible) in the pairs of words. The most frequent pairs are illustrated below (figures in brackets show the overall number of cases in which strong and weak alliteration, as well as vowel alliteration, occur).

$1+2(245)$ :

Посни понӧль вожъяс костысь (1: 55) 'Of the branches of the thicket';

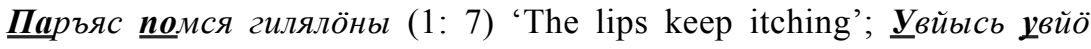
чеччалісны (41: 36) 'From one branch to another they jumped'.

$1+3$ (269):

Вышна кияс выл чукӧртісны киввъяс (1: 68) 'The birds have picked the songs'; $\underline{\boldsymbol{O}}$ шлӧн паськыд ордылм вылын (9: 127) 'On the bear's wide path'.

$1+4(161)$ :

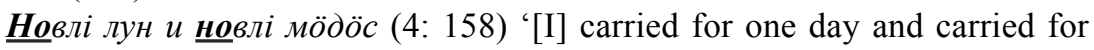
another one'; Медылм луныс пуксис мича (1: 99) 'So that the day would

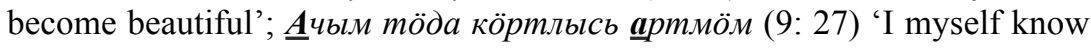
how iron was born'.

$2+3$ (204):

Кӧні позис позтор вӧчны (1: 181) 'Where would a nest be made'; Сійӧ вё

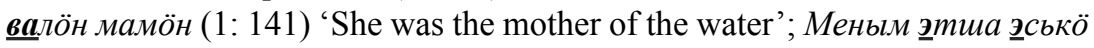
ковмис (4: 223) 'Little would be needed by me'.

$2+4$ (219):

Ошлысь кок туйяссӧ корсьӧ (9: 122) 'Bear's footprints are seeking out'; Тӧльсс п्̈̈льтіс сылль пй̈с (1: 132) 'The wind has blown a son to her'; Holpblc

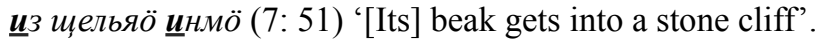


$3+4(145)$ :

Лэчыд шылурт дорччысь дорис (9: 98) 'A sharp sword the forger has forged';

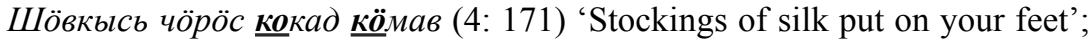
Кор ме $\underline{\boldsymbol{a}} д$ за аслам синмӧн (10: 115) 'When I see with my own eyes'.

Less frequent are the following variations of word pairs: $1+5$ (31 cases), $3+5$ ( 29 cases), $2+5$ ( 28 cases), $4+5$ ( 22 cases), $3+6$ ( 6 cases), $1+6$ ( 2 cases $), 2+6$ ( 2 cases), 4+6 ( 1 case), $5+7$ ( 1 case).

\section{$\mathbf{a}-\mathbf{a}-\mathbf{a}$}

The consonance of three words in a line occurs in 107 cases (7\%). With respect to the intensity of alliteration, i.e. the proportion of weak (W) and strong $(\mathrm{S})$ consonance, the following kinds of alliteration are observed: W-W-W (61 cases), S-S-S (5 cases), S-W-S (17 cases), W-S-S (14 cases), S-S-W (10 cases). From the point of view of the location of the consonant words within a line, 13 various combinations are identified. The most frequent of them is W-W-W, followed by S-S-S, S-W-S, W-S-S, S-S-W. Below are examples of the most frequent variations of consonant words in this type of alliteration (figures in brackets show the number of observations).

$1+3+4(24)$ :

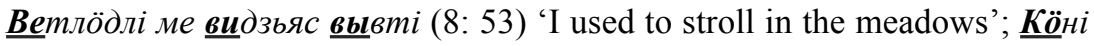

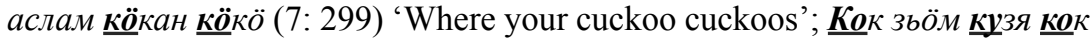

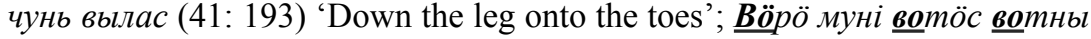

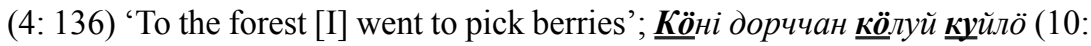
269) 'Where the blacksmith's belongings are'.

$2+3+4(14)$ :

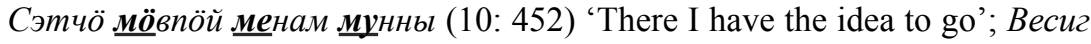
дорччыссы дугдіс дорны (34: 20) 'Even the blacksmith stopped forging';

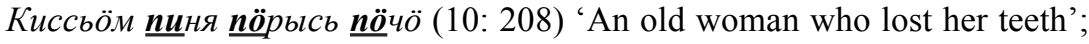

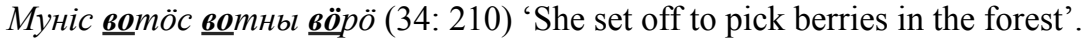

$1+2+3(23)$ :

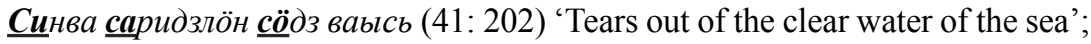
$\underline{\boldsymbol{\Gamma} а ж т о ̈ м ~ г а ж н а с ~ г а ~ ж о ̈ д ч о ̈ н ы ~(5: ~ 31) ~ ' T h e y ~ a r e ~ r e j o i c i n g ~ i n ~ j o y l e s s ~ d e l i g h t ' ; ~}$ $\underline{\boldsymbol{C и}} н ъ я с ы с ь ~ \underline{\text { сӧ}} \partial з$ синва петіс (4: 469) 'Out of the eyes clear tears came';

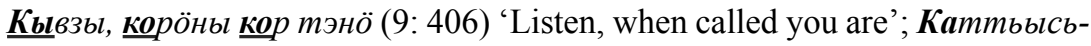
кавшась коз пу вылас (10: 135) 'Climb up the spruce'. 
$1+2+4(19)$ :

$\underline{\boldsymbol{T a}}$ чӥ тӧв в ныр муйяс бокӧд (10: 181) 'Here past the whirlwinds' paths'; Петӧ пемӧс бӧрся пемӧс (41: 32) 'One beast after another come out';

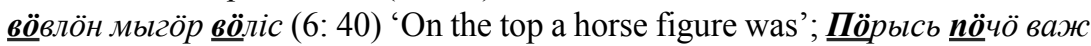

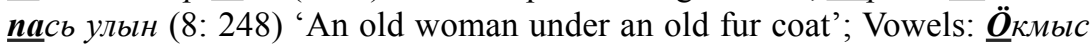
олӧм мортлысь в $\underline{\boldsymbol{o}}$ ліс (1: 137) 'Has lived eight lives of a human being'; $\underline{\boldsymbol{O}}$ ла асссьылм лӧсьыьд олӧм (4: 112) 'I am living my good life'.

Among the other variants are: $2+3+5$ ( 8 cases), $2+4+5$ ( 4 cases), $1+2+5$ ( 4 cases), $1+3+5$ ( 4 cases), $3+4+5$ ( 2 cases), $2+3+6$ ( 2 cases), $3+4+6$ ( 1 case $), 1+3+6$ ( 1 case $), 1+4+5$ ( 1 case $)$.

\section{a-a-a-a}

Some of the lines in the translation offer examples of consonance based on four words ( 6 examples, or $0.4 \%$ ). From the point of view of weak and strong alliteration contained in these examples, they belong to the following kinds of consonance:

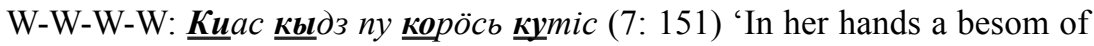
birch she was holding'.

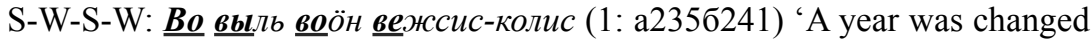
by a new year'.

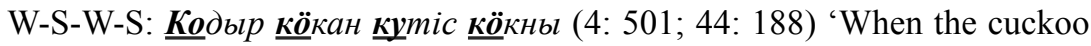
started cuckooing'.

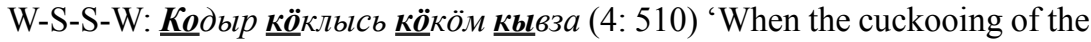
cuckoo I hear'.

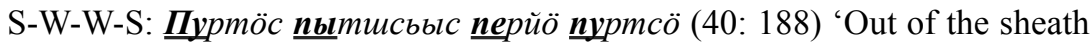
[he] gets the knife'.

\section{$\mathbf{a - a}+\mathbf{b}-\mathbf{b}$}

In some of the lines of the translation alliteration is based on two pairs of words (54 cases, or 3.5\%). With respect to the intensity of alliteration, the following combinations of weak and strong alliteration occur in the pairs: $\mathrm{S}+\mathrm{S}$ (17 cases), $\mathrm{W}+\mathrm{W}$ ( 25 cases), $\mathrm{S}+\mathrm{W} / \mathrm{W}+\mathrm{S}(12$ cases). From the point of view of the location of the consonant words in a line, 13 variations are observed. The most frequent combinations are: $\mathrm{S}+\mathrm{S}, \mathrm{W}+\mathrm{W}, \mathrm{S}+\mathrm{W} / \mathrm{W}+\mathrm{S}$. Variation in the combinations of the consonant words is shown below (figures in brackets show the number of observations). 
$1+42+3(12)$ :

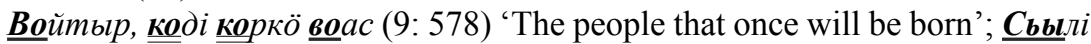

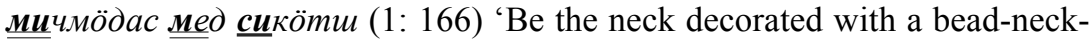

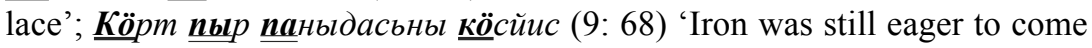

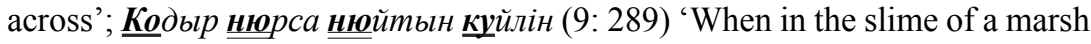
[you] were lying'.

$1+32+4(11)$ :

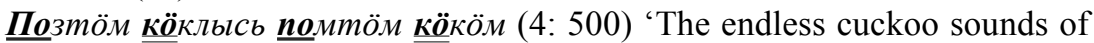

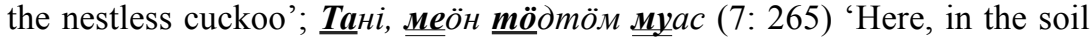

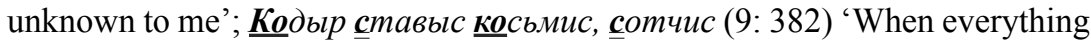

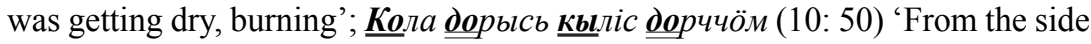
of the smithy he heard the sounds of forging'.

$1+42+5(7):$

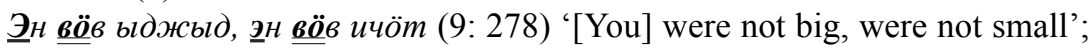

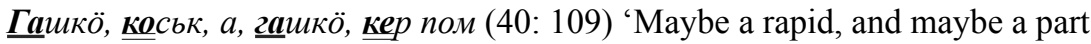
of a $\log$.

$1+62+5(7):$

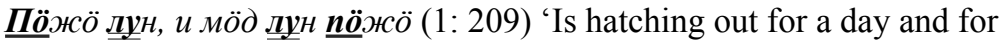
another day is hatching out'.

$1+23+4(7)$ :

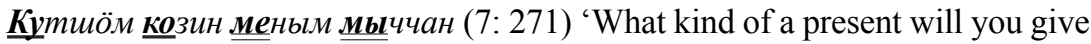

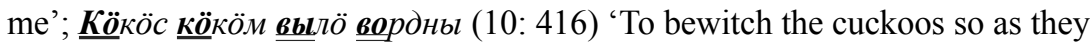

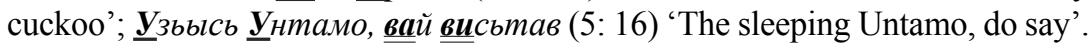

Among the rare variations of consonance based on four words are such combinations as $1+32+5$ and $1+43+5$ that occur twice and $1+2$ $4+6 ; 1+52+3 ; 1+24+5 ; 2+34+5 ; 1+53+4 ; 1+52+4$ that occur only once.

\section{$a-a+b-b-b$}

The pairs of consonant words were found to be complex in some lines - one of the members of the pairs consisted not of two but of three words ( 7 examples, or $0.45 \%$ ):

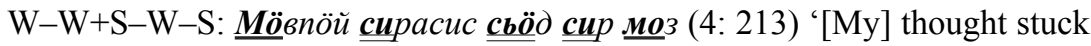

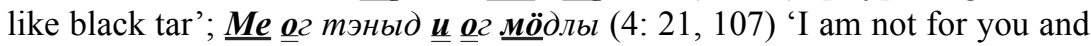

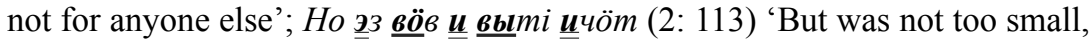




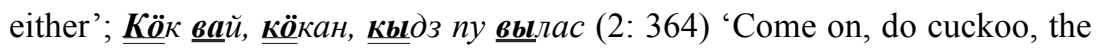
cuckoo on the birch';

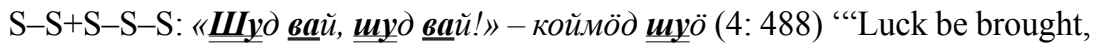
luck be brought!" - the third one says';

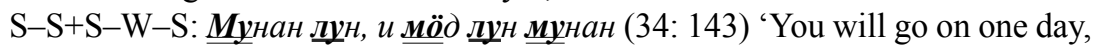
and on the second day you will go'.

There are also lines in which all (or almost all) the words are consonant. Consonance in such lines is of the following types: $a-a-a$ and $a-a-a-a$. Examples of lines in which all the words are consonant are given above in the previous parts that describe the two types of alliteration. Here are more examples of such consonance:

Сійӧ тэныд бур кыв сетас, $\quad$ She will give you good advice,

Кылзи веськылд туйӧд мунны, , How to go along a straight road,

Медым помӧдз шог эз жугӧд, So that you are not broken by grief,

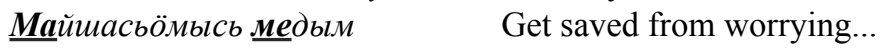

$\underline{\text { Mbl }}$ нны... (5: 218-222) (Analogous lines: 5: 211)

Acсьвыс биа вужсӧ лэптіс, The fiery bow he lifted,

Веськыд пельпом бердас пуктіс, То the right shoulder put,

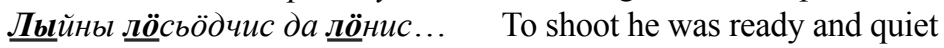

(6: 147-149) he was...

Дзизгигтырйи сійӧ лэбалӧ... $\quad$ Buzzing it is flying ...

...

$\underline{\boldsymbol{K o}}$ дзувкотлысь $\underline{\boldsymbol{\kappa} \boldsymbol{\gamma} д з с о ̈ ~ \underline{\boldsymbol{k b l}} с к о ̈ . . . ~ T h e ~ u r i n e ~ o f ~ a n t s ~ i t ~ i s ~ c a r r y i n g ~ . . . ~}$

(9: 237-..-242)

Сэки Похъёласа инька

Cетіс сёйнь-юны сылы,

Пуксьӧдіс паруса пьюжӧ...

(10: 455-457)

Гашкӧ, Похъёлаысь сюрӧ,

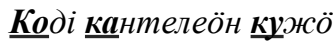

Бура ворсны, гажлун корсьныл... (40: 287-289)

Ворсан везъяс вежыньтчисны, The musical strings became curved, Вӧв бӧж сіяс орласисны ...

(40: 305-306)
Then the old woman of Pohjola Gave food and drinking to him

Set in a sailing boat ...

Maybe, in Pohjola is someone

Who the psaltery will

Well play, joy will seek ...
The horsehairs got torn ... 
Alliteration in some cases crosses the border of one line and links the words of two or more lines:

Шӧвк сунисысь тывсё чӧвтіс, The seine of silk thread he cast, Надзӧн бӧра-водза кыскис... Slowly forward backward he drew...

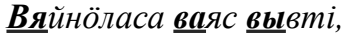
In the waters of Väinölä, Калевала венӧр вомӧн... Through the isthmus of Kalevala...

(5: $141-\ldots-147)$

$\underline{\boldsymbol{\kappa} \boldsymbol{b}} \kappa$ дай 뜨им войков бӧрдіс, $\underline{\boldsymbol{\kappa}}$ зь лунъясӧн синва кисьтіс, Эз тӧд, кйmысь туйсӧ коросьның... (7: 125-128)

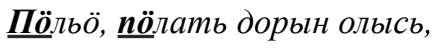
Еджыд тошка паччӧр п्̈̈жысь... (8: 270-271)

Тадзи коймӧд во тшӧти колис

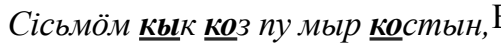

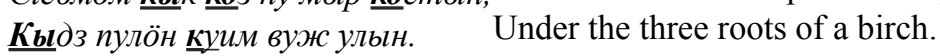
(9: 90-92)

Сэтчӧ мёвпойй менам муннны, Чужан муын медым кувныс... (10: 452-453)

Мамыс 쓰 дводдзаӧн корсьӧ,

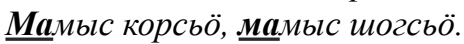

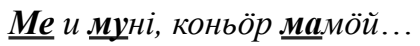
(34: 218-220)

Мечнас зургис саридз гыӧ, Пемыд ваӧ, пыжныс улӧ, Пӧрысь сирль пельпомъясас... (40: 159-160)
For two and three days and nights he wept, For long days tears shed, Did not know where the way to seek...

An old man beside the stove living, A white-bearded, sleepyhead ...

Thus a third year [iron] passed Between two rotten spruce stumps,

There I have the thought to go, In my homeland to die...

Mother is the first to seek, So I set off, a poor mother...

With his sword [he] hit the wave, Into the dark water, under the boat, Into the shoulders of old pike... Mother seeks, mother is in grief.

The examples of alliteration and data on the occurrences of alliteration in the translation of the Kalevala by Adolf Turkin provided above allow the suggestion that the translator may have attempted to find consonant words (three and more) and to introduce them into the text. However, alliteration observed in the translation cannot be regarded as a characteristic phonetic factor that participates in the organisation of the text. It proves to be accidental, not structural. 
The fact that the structural features of the Komi language differ from those of the Finnish literary language and from the language of the Kalevala explains the limitations in the translation of such a device as alliteration. From the point of view of the differences in the phonetic features between the two languages it can be noted, for example, that Komi has 33 phonemes ( 7 vowels and 26 consonants) while in Finnish the phonemes are less numerous -21 ( 8 vowels and 13 consonants) (SKJa I: 14, ISK: 37-38). As a consequence, words with the same initial vowels and consonants in Komi are fewer than in Finnish. As far as lexis is concerned, consonant words that would make pairs of synonyms (both in the literary language and dialects) are fairly rare in Komi.

\section{Some conclusions}

To draw a comparison between the results of this analysis and data available on other translations of the Kalevala, the frequency of alliteration in several translations, as shown below (see Table 1), is considered. Some of the data derive from analyses of the occurrences of consonant words in the original text of the Kalevala and in five translations of the epic into Hungarian provided by László Lisztóczky, a Hungarian author. Lisztóczky has made observations of the occurrences of alliteration in the Hungarian translations by Ferdinánd Barna (Kalevala 1871), Béla Vikár (Kalevala 1985a), Kálmán Nagy (Kalevala 1975), István Rácz (Kalevala 1980), and Imre Szente (Kalevala 2001). The observations are based on three fragments taken from three runes - rune 2: lines 1-100, rune 4: lines 100-200, rune 9: lines 1-100 (see: Lisztóczky 1998: 109, Varga 2010: 124, 135). In addition to the aforementioned findings on the Hungarian translations, the table includes our data based on the same fragments from the three runes translated into Komi by Adolf Turkin. The table also contains data obtained in our observations of the Estonian translation by August Annist (Kalevala 1985b) and of two Russian translations - by Leonid Belski (Kalevala 1984), and by Eino Kiuru and Armas Mishin (Kalevala 1998). For comparison, our data on the occurrences of alliteration in the Komi translations of rune 41 (91 lines) by Adolf Turkin (Turkin 1980) and by Vasili Lytkin (Kalevala 1929) are also given.

The table shows that the occurrences of alliteration in the Estonian translation are comparable with those in the original text. 
Table 1. The occurrences of alliteration in the Kalevala and in the translations of the epic into Hungarian, Estonian, Russian, and Komi

\begin{tabular}{|c|c|c|c|c|c|}
\hline Rune: lines & & $2: 1-100$ & 4: 100-200 & $9: 1-100$ & 41 \\
\hline Original text & & 80 & 83 & 80 & \\
\hline \multirow{5}{*}{$\begin{array}{l}\text { Hungarian } \\
\text { translations }\end{array}$} & F. Barna & 21 & 19 & 23 & \\
\hline & B. Vikár & 56 & 43 & 54 & \\
\hline & K. Nagy & 56 & 51 & 67 & \\
\hline & I. Rácz & 100 & 99 & 100 & \\
\hline & I. Szente & 194 & 137 & 174 & \\
\hline $\begin{array}{l}\text { Estonian } \\
\text { translation }\end{array}$ & A. Annist & 97 & 87 & 81 & \\
\hline \multirow{2}{*}{$\begin{array}{l}\text { Russian } \\
\text { translations }\end{array}$} & L. P. Belski & 35 & 28 & 29 & \\
\hline & $\begin{array}{l}\text { E. Kiuru, } \\
\text { A. Mishin }\end{array}$ & 34 & 35 & 35 & \\
\hline \multirow{2}{*}{$\begin{array}{l}\text { Komi } \\
\text { translations }\end{array}$} & A. Turkin & 35 & 51 & 48 & 33 \\
\hline & V. Lytkin & & & & 39 \\
\hline
\end{tabular}

As far as the data on the Russian translations is concerned, it is evident that there is only a slight difference between the occurrences of alliteration in the two versions. However, the data on the Russian translations differ considerably from those on the original text. This difference might be conditioned by the typological and structural peculiarities of the two languages. The translators were aware that attempts to convey this feature of the original would be wasted (Bel'skij 1915: xxiii, Mišin 1998: 14).

In the Komi translation by Adolf Turkin, the occurrences of alliteration are more frequent than in the Russian translations, but are not as frequent as in the original - there is a considerable difference in the data. It can be assumed that the Russian and Komi translators avoided using artificial means to convey alliteration and that consonance observed in the translations is accidental. The fact that alliteration in the Komi translations occurs more frequently than in the Russian translations, implies that the Komi language offers more resources for the use of consonant words than the Russian language.

The data on the Komi translation by Adolf Turkin are comparable with the data on the Hungarian translations by Béla Vikár and Kálmán Nagy. In the translation by Ferdinánd Barna alliteration occurs rarely, 
while in the translations by István Rácz and Imre Szente it is by far more frequent than in the original text. Taking into account the observations based on the Komi translation and the Hungarian translations by Béla Vikár and Kálmán Nagy, it is possible to assume that the Komi and Hungarian languages might be more or less equally predisposed to the realisations of the phenomenon of alliteration.

Data concerning alliteration in two translations of rune 41 (91 lines) into Komi do not differ much, although the version provided by Vasili Lytkin appeared 60 years earlier than that provided by Adolf Turkin. The earlier version has been written, to all appearances, via a Russian text. Adolf Turkin, according to his statement (Turkin 1985e: 9), did not set the aim of conveying the alliteration used in the original text. Taking into account the results of this analysis we propose that the Komi language has a predisposition to consonance. Komi is more predisposed to consonance than Russian but less so than Finnish and Estonian. From this point of view, our data show an analogy between Komi and Hungarian.

\author{
Address: \\ Nikolay Rakin \\ University of Tartu \\ Jakobi 2 \\ 51014 Tartu, Estonia \\ E-mail: rakin@ut.ee
}

\title{
References
}

Bel'skij, Leonid P. (1915) "Predislovie k" pervomu izdaniju”. In Kalevala. Finskij narodnyj èpos”. Perevod L. Bel'skago. Izdanie vtoroe, ispravlennoe i snabžennoe primečanijami, xiii-xiv. Moskva.

ISK = Auli Hakulinen, Maria Vilkuna, Riitta Korhonen, Vesa Koivisto, Tarja Riitta Heinonen, and Irja Alho (2010) Iso suomen kielioppi. Helsinki: Suomalaisen Kirjallisuuden Seura.

Kalevala. Karelo-finsköj epos. 44-öd s'ylankyv. Kantelelön čužöm. Finsköj kyv vylys' vudžödis A. I. Turkin. Rukopis'. Muzej istorii prosveščenija Komi kraja. OF 16012.

Kalevala 1871 = Kalevala. A finnek nemzeti eposza. Az eredetiböl forditotta Barna Ferdinánd. Pest.

Kalevala 1929 = "Vejnemejnelön kanteleön vorsöm“. In Illa Vas'. Kyvburjas, 215-218. Syktyvdinkar.

Kalevala 1975 = Kalevala. Forditotta Nagy Kálmán. Budapest: Európa Könyvkiadó. 
Kalevala 1980 = Kalevala . Forditotta, kíserö tenulmánnyal ellátta és felvételeket készitette Rácz István. Budapest: Európa Könyvkiadó.

Kalevala $1984=$ Kalevala . Perevod s finskogo L. P. Bel'skogo. Leningrad.

Kalevala 1985a = Kalevala. A finn eredetiböl forditotta Vikár Béla. Budapest: Helikon Kiadó.

Kalevala 1985b = Kalevala. Koostanud Elias Lönnrot. Tõlkinud August Annist. Tallinn: Eesti Raamat.

Kalevala 1998 = Elias Lönnrot. Kalevala. Eeppinen runoelma karjalaisten ja suomalaisten muinaisten kansanrunojen pohjalta. Èlias Lënnrot. Kalevala. Èpičeskaja poèma na osnove drevnix karel 'skix i finskix narodnyx pesen. Perevod È. Kiuru i A. Mišin. Petrozavodsk.

Kalevala $2001=$ Kalevala . Forditotta Szente Imre. Szombathely.

Karhu, Ėjno (1978) "Perevod, ne modernizacija (O poètičeskix perevodax run 'Kalevaly')". In Ot run k romanu. Stat'i o karelo-finskom fol'klore, "Kalevale”, finskoj literature, 118-137. Petrozavodsk.

Laugaste, Eduard (1962) "Eesti alliteratsioonist ja assonantsist". Keel ja Kirjandus 9, 531-537.

Laugaste, Eduard (1968) "Sõnaalguline ja sisealliteratsioon eesti regivärssides". Looming 12, 1873-1882.

Leino, Pentti (1970) Strukturaalinen alkusointu suomessa: Folklore-pohjainen tilastoanalyysi. Helsinki: Suomalaisen Kirjallisuuden Seura.

Lisztóczky, László (1998) A csodaszarvas a Kalevala erdejében: Fejezetek a finn eposz magyarországi történetéböl. Gyöngyös: Pallas.

Mišin, Armas (1998) “'Kalevala' - poèma Lënnrota”. In Elias Lönnrot. Kalevala. Eeppinen runoelma karjalaisten ja suomalaisten muinaisten kansanrunojen pohjalta. Èlias Lënnrot. Kalevala. Èpičeskaja poèma na osnove drevnix karel'skix i finskix narodnyx pesen. Perevod Ė. Kiuru i A. Mišin. Petrozavodsk.

Semenova, Marianna Ju. (2001) “Alliteracija po mestopoloženiju v karelo-finskix runax i marijskix jazyčeskix molitvax. Finno-ugrovedenie 2, 112-118.

SKJa I = Sovremennyj komi jazyk. Učebnoe posobie dlja vysšix učebnyx zavedenij. Čast' pervaja. Fonetika, leksika, morfologija. Pod red. prof. V. I. Lytkina. Syktyvkar. 1955.

Turkin, Adolf I. (1980) “Kalevala. Vjajnjamöjnen vorsö kanteleön. Vudžödis A. I. Turkin". Vojvyv kodzuv 6, 40-42.

Turkin, Adolf I. (1984) “Kalevala. Ilmarinen dorö Sampo. X s'ylankyv. Vudžödis A. I. Turkin". Vojvyv kodzuv 4, 36-41.

Turkin, Adolf I. (1985a) “Kalevala. I s’ylankyv. Vodzkyv. Mu puks'öm. Vudžödis A. I. Turkin”. Vojvyv kodzuv 7, 10-13.

Turkin, Adolf I. (1985b) “Kullervo addzö bat'-mamsö. "Kalevalays”" 34-öd s'ylankyv. Vudžödis A. I. Turkin”. Jugyd tuj, 23 ijulja.

Turkin, Adolf I. (1985c) "Vjajnjamöjnen vöčö kantele. Vudžödis A. I. Turkin”. Jugyd tuj, 28 fevralja.

Turkin, Adolf I. (1985d) “Vjajnjamöjnen vöčö kantele. “Kalevalalön” 40-öd s’ylankyv. Vudžödis A. I. Turkin". Jugyd tuj, 5 marta.

Turkin, Adolf I. (1985e) ““Kalevalaly”- 150 vo”. Vojvyv kodzuv 7, 8-9. 
Turkin, Adolf I. (1987) “Mu ködzöm. Möd s’ylankyv. Vudžödis A. I. Turkin”. Jugyd tuj, 23 ijunja.

Turkin, Adolf I. (1991) “Kalevala. Kojmöd s’ylankyv. S’ylömön vermas’öm. Vudžödis A. I. Turkin". Komi mu, 5 dekabrja.

Turkin, Adolf I. (1996) "Kalevala. Nël'öd s’ylankyv. Vjajnjamöjnen da Ajno nyv. Vudžödis A. I. Turkin". Vojvyv kodzuv 7, 59-67.

Turkin, Adolf I. (1999) “Kalevala. S'ylan panas. Mu puks'öm. Vjajnjamöjnenlön čužöm. Vudžödis A. I. Turkin”. Vojvyv kodzuv 12, 3-9.

Turkin, Adolf I. (2000a) “Kalevala. Vitöd s'ylankyv. Vellamolys' nyvsö vugyrtöm. Vudžödis A. I. Turkin”. Vojvyv kodzuv 1, 3-7.

Turkin, Adolf I. (2000b) "Kalevala. Kvajtöd s’ylankyv. Ëukahajnen vodzös myntö. Vudžödis A. I. Turkin”. Vojvyv kodzuv 2, 56-69.

Turkin, Adolf I. (2000c) "Kalevala. Sizimöd s'ylankyv. Vjajnjamöjnen Pox”ëlayn. Vudžödis A. I. Turkin”. Vojvyv kodzuv 4, 60-66.

Turkin, Adolf I. (2000d) "Kalevala. Kök”jamysöd s’ylankyv. Vojvyvsa nyv. Pyž vöčöm. Vudžödis A. I. Turkin”. Vojvyv kodzuv 6, 44-48.

Turkin, Adolf I. (2000e) "Kalevala. Ökmysöd s'ylankyv. Pidzös doj burdödöm. Vudžödis A. I. Turkin“. Vojvyv kodzuv 7, 37-47.

Varga, Ildikó P. (2010) Hiisi szarvasától a csodaszarvasig: A Kalevala magyar fordításai. (Erdélyi tudományos füzetek, 266.) Kolozsvár: Erdélyi Múzeum-Egyesület.

Kokkuvõte. Nikolay Rakin: Alliteratsioon Kalevalas ja eepose Adolf Turkini komikeelses tõlkes. Alliteratsioon on Kalevala juhtivaid stiilivõtteid. Adolf Turkini komikeelse Kalevala tõlke analüüs näitab, et soomekeelse eepose eeskujul esineb alliteratsioon üsna sageli ka komikeelses tekstis. Alliteratsiooni esinemine tõlkes laseb väita, et tõlkija on püüdnud leida võimalikke algriimis olevaid sõnapaare ja neid kasutanud. Sellest hoolimata ei ole alliteratsioon eepose komikeelses tõlkes teksti iseloomustav ja korrastav foneetiline faktor, jäädes juhuslikuks, mitte strukturaalseks nagu algtekstis. Kalevala komi tõlkes on 5132 värssi, alliteratsioon esineb neist 1539-s ehk tõlke igas kolmandas värsis. Näidete põhiosas on tegemist nõrga alliteratsiooniga, tugev alliteratsioon on üsna haruldane. Alliteratsiooni sisaldavad sõnad algavad 28 erineva häälikuga (nendest 21 on kaashäälikud ja 7 täishäälikud). Kõige sagedamini esinevad sõnapaarid algushäälikutega $[\mathrm{k}],[\mathrm{v}],[\mathrm{p}],[\mathrm{m}] \mathrm{ja}[\mathrm{s}]$. Tugev alliteratsioon on sõnaalgulise silbi ( $25 \%$ algriimilistest värssidest) ja samatüvelise sõna (25\% algriimilistest värssidest) kordus. Alliteratsiooni kasutuse erinevused algtekstis ja tõlkes tulenevad komi keele foneetilistest ja leksikaalsetest omadustest. Võrreldes soome keelega on komi keeles rohkem foneeme (33 versus 21 ) - tulemuseks on samasuguse algusega sõnade väiksem arv. Komi sõnavaras puudub vajalik hulk sünonüüme, mille seast võiks leida algriimilisi sõnapaare.

Märksõnad: Kalevala, alliteratsioon, komi keel, tõlkimine 